\title{
Wind Power and Job Creation
}

\author{
Luigi Aldieri ${ }^{1, *(\mathbb{C}}$, Jonas Grafström ${ }^{2}{ }^{\mathbb{D}}$, Kristoffer Sundström ${ }^{3}$ and Concetto Paolo Vinci ${ }^{1}$ \\ 1 Department of Economic and Statistical Sciences, University of Salerno, 84084 Fisciano, Italy; \\ cpvinci@unisa.it \\ 2 Department of Business Administration, Technology and Social Sciences, The Ratio Institute and Luleå \\ University of Technology, SE-11359 Stockholm, Sweden; jonas.grafstrom@ratio.se \\ 3 The Ratio Institute, SE-11359 Stockholm, Sweden; kristoffer.sundstrom@ratio.se \\ * Correspondence: laldieri@unisa.it
}

Received: 3 November 2019; Accepted: 18 December 2019; Published: 19 December 2019

\begin{abstract}
The purpose of this paper is to provide a global overview of job effects per MW of wind power installations, which will enable improved decision-making and modeling of future wind-power projects. We found indications that job creation connected to wind-power installations is rather limited. In total, 17 peer-reviewed articles and 10 reports/non-peer-reviewed papers between 2001 and 2019 were assessed. Our three major policy conclusions are as follows: (a) job creation seems to be limited; (b) each new project should consider a unique assessment, since all projects have been undertaken within different institutional frameworks, labor markets, and during separate years, meaning that the technology is not comparable; and (c) the number of jobs depends on the labor intensity of the country.
\end{abstract}

Keywords: wind power; jobs; labor; renewable; policy; energy

\section{Introduction}

\subsection{Background and Motivation}

There is an increasing interest in the effects of investments conducted in wind power on the labor market [1]. After a slow European labor market recovery following the financial crisis, attention has been directed to the labor market effects of renewable energy policies [2-5]. The importance of renewable energy for mitigating climate change is not contested [6-9], but politicians who manage budget constraints must select policies that match their electorate's preferences and, hence, sometimes, motivate renewable-energy spending with job creation [10].

However, despite the rhetoric about job creation, a comprehensive recent literature review establishing large job effects from wind-power development is mostly absent (see Cameron and van der Zwaan [11] for a broad review of several renewable-energy sources). From the beginning of the 21th century, some efforts to quantify employment from climate policies, specifically from renewable energy technology, have been made [3,4]. Whilst previous studies differ in methods and assumptions, they often apply a common metric to assess potential employment: jobs (or jobs-year) created per installed capacity [1]. Results for different assessments vary largely due to distinct methodological approaches. Thus, results are not directly comparable or applicable to other contexts without references to other studies.

The purpose of this paper is to provide a global overview of job effects per MW of wind-power installations, which will enable improved decision-making and modeling of future wind-power projects. The research is highly relevant, since, for example, in the International Renewable Energy Agency's report [12] "Renewable Energy and Jobs-Annual Review 2019", the following is stated: 
Employment opportunities are a key consideration in planning for low-carbon economic growth. Many governments have prioritised renewable energy development, firstly to reduce emissions and meet international climate goals, but also in pursuit of broader socio-economic benefits.

Hence, policy makers will make decisions regarding wind-power expansion, with the creation of jobs in mind, and researchers and other personnel who are preparing the documents for the decision makers need material to base their decisions and modeling on. This paper therefore provides valuable insights for policy makers, researchers, and modelers, by doing the following: (a) extend existing literature reviews with papers going as far as to the year 2019, revealing jobs/MW in different projects; (b) present the modeling approaches used in the literature to highlight the large variance in approaches; and (c) present a range for jobs created per MW. The knowledge provided in this paper is, hence, an enabler for further policy decisions. We present and discuss why it is hard to make a precise prediction, something that should be included in future evaluations of the job effects, and we also present the different cases in a way that makes it somewhat easy to find similar projects to the one a modeler or researcher wants to evaluate.

To empirically investigate the issue, we assessed both research literature and policy papers (separately), extracting and from the papers, where possible, and calculating the number of added jobs per installed MW. In order to create comparability between the various studies, to the best of our ability, we adopt a simple normalization to calculate average employment per unit of energy, namely job-years per MW. Many papers present a relationship between MW installed and number of jobs, but the use of a job/MW ratio is problematic, due to differences in for example the export/import capacity [13]. Big wind-turbine manufacturers-including major subcomponents-in countries such as Denmark and Germany, are responsible for a lot of domestic job creations, whilst the MW might be installed abroad [1]. We are aware that the level of usefulness for the jobs/MW indicator has limitations due to definition discrepancy of wind-energy-related jobs and import-export relations.

Some studies $[14,15]$ only look at direct job creation, whilst other consider indirect jobs [16-18] which are harder to measure. Another obstacle a researcher will find when trying to quantify employment levels in the wind energy sector is the nonexistence (in some countries) of an official classification of the companies that are part of the sector (and general lack of detail in official statistics).

We conclude that there is never a simple yes-or-no answer to the question if wind energy development has a large employment effect. The understanding of the term employment varies among scholars, and so do the measurements. As a result, the same scenario can lead to completely different conclusions, depending on the approach taken by the researcher.

Is it meaningful to review a rather limited amount of literature, or is it worthwhile to wait a few years for more papers to be published? Our answer is that more would of course be better, but there is also a value for policy makers to be enlightened to the fact that there is limited proof of an extraordinary job creation from wind-power construction projects. The gathered numbers do tell us something even though we are careful when making calculations and predictions with them as the base. Considering the coming billion-dollar investments in the coming years and the rapid energy system transition, more information is valuable [19].

\subsection{Scope}

Due to a limited number of regional (e.g., Europe) papers concerning the employment originating from wind power construction, we look at projects globally. We have predominantly focused on peer-reviewed articles and some reports which are-even if not exclusively peer- reviewed, as best as we can judge, in line with academic standards-well described (and cited) in the scientific literature. In total, 17 peer-reviewed and 10 reports are identified.

The focus has mainly been on onshore instalments. The reason is twofold: Firstly, there was a very limited number of studies that looked at offshore, in particular, in a meaningful way for our study. Secondly, the vast majority of installed wind power-capacity has been conducted onshore, and, consequently, more studies have been written (see Figures 1 and 2 for comparison). 
Onshore is presently the main sources of wind energy and employment, but not necessarily in the near future. Bilgili, Yasar, and Simsek [20] estimate employment in offshore wind energy to bypass onshore employment by year 2025 and that offshore wind farms will contribute to more jobs per MW than their onshore counterparts. Investment costs differ between onshore and offshore wind farms: Onshore wind farms have an average investment cost of approximately 1.23 million $€$ per MW, while offshore wind farms have an investment cost ranging from 1.2 to 2 million $€$ per MW. Investment costs for offshore wind farms are affected by distance to coast and water depth. [20].

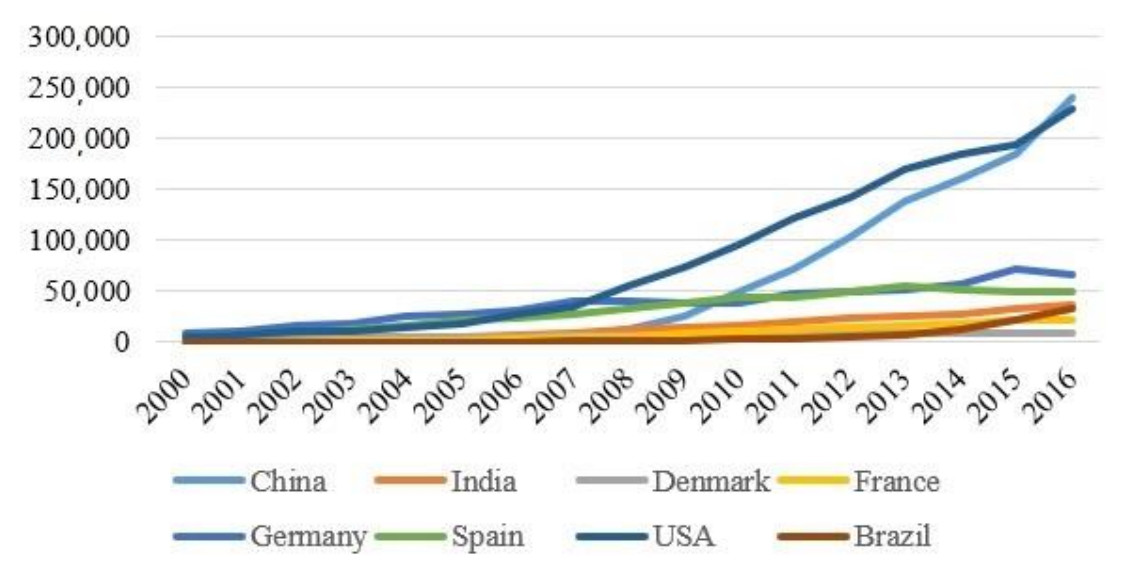

Figure 1. Generation capacity onshore wind power (GWh). Source: IRENA [21], Renewable Energy Statistics 2018, The International Renewable Energy Agency, Abu Dhabi.

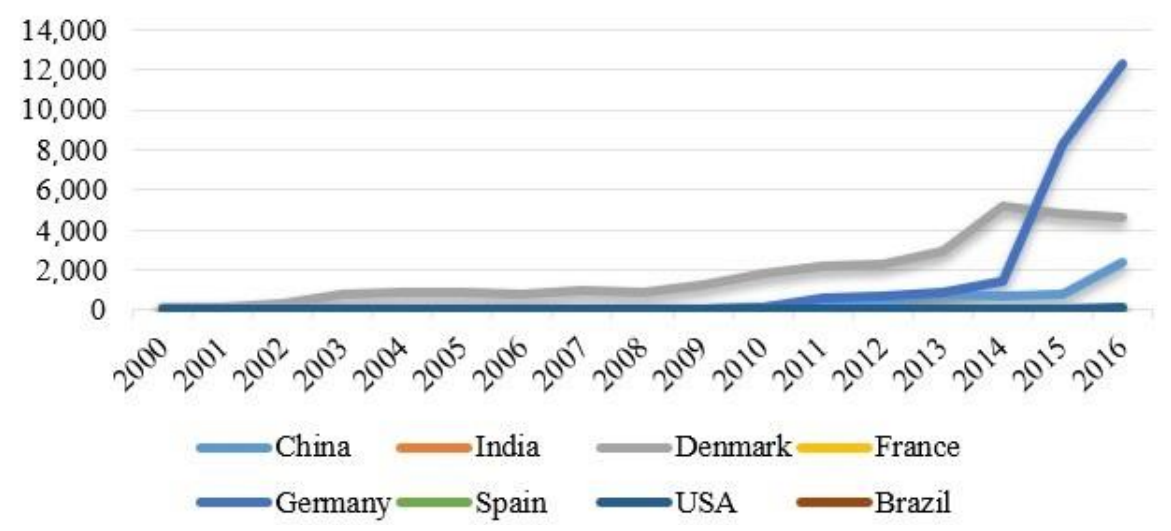

Figure 2. Generation capacity offshore wind power (GWh). Source: IRENA [21], Renewable Energy Statistics 2018, The International Renewable Energy Agency, Abu Dhabi.

\subsection{Approach}

In this paper, we present the results from desktop research performed to identify academic articles and reports (grey literature) on the jobs/MW created by wind-power projects. Systematic literature reviews should be replicable, scientific, and have transparent methods, and they should allow readers to follow the path researchers took to arrive at their findings. We followed the process found in Tranfield, Denver, and Smart [22], which comprises three steps: planning, execution, and reporting. In the planning step, we define the keywords of interest and a protocol for realizing the chosen approach.

We employed a combination of different keywords in our search. Specifically, we carried out searches consisting of terms such as "wind power jobs" or "wind power employment", on the one hand, and "green jobs", "renewable employment effects", and "employment energy", on the other, in key bibliographic databases, such as Google Scholar, Web of Science, Science Direct, and Wiley Online Library. 
We started with selecting the academic articles, as they are expected to embody serious research work, aiming at expanding knowledge, and have been validated by the scientific community through the peer-review processes [23]. All articles were evaluated to confirm that the paper considered undoubtedly fit the scope of our topic. Any article that did not deal with the topic area or that played a minor role was not considered. However, articles in which the topic appeared as a significant subtheme were included.

The abstracts to these studies were then, as the first step, read, to eliminate irrelevant articles that did not contain any empirical investigations of job effects. In the second step, articles with applications for our research purpose were chosen for a deep read. Those studies where job findings were only mentioned because they had been identified in previous studies were not considered, only their original source, to avoid one job paper being counted twice, although only empirically valid once. Furthermore, we excluded articles that did not use previous construction as a base for job estimation. We then proceed with a content analysis, which can be defined as follows [24]:

A research technique for making replicable and valid inferences from texts (or other meaningful matter) to the contexts of their use.

Content analysis comprises procedures which are expected to be reliable, replicable, and valid. In the analysis, a researcher and a research assistant read the content to ensure the validity and reliability of the results rather than trusting the judgements from a single person [25]. An example of the protocol is listed in Table 1.

Table 1. Research protocol example.

\begin{tabular}{|c|c|c|c|c|}
\hline Study & $\begin{array}{l}\text { Case, Method, and } \\
\text { Period }\end{array}$ & Results & Direct Jobs & Indirect Jobs \\
\hline Moreno and López [26]. & $\begin{array}{c}\text { Spain, Asturias, } \\
\text { analytical model } \\
\text { (literature review), } \\
\text { 2005-2010. }\end{array}$ & $\begin{array}{c}\text { The Renewable Energy } \\
\text { Development Plan 2000-2010 sets } \\
\text { policies to reach the point where } \\
29.4 \% \text { of generated electricity } \\
\text { comes from renewable energy } \\
\text { sources in the domestic market. } \\
\text { This will affect Spain as a country, } \\
\text { as well as the Principality } \\
\text { of Asturias. }\end{array}$ & $\begin{array}{c}13.2 \text { job-years/MW; } \\
13 \text { job-years/MW in } \\
\text { construction and installation; } \\
0.2 \text { job-years/MW in } \\
\text { Operations and } \\
\text { Maintenance (O\&M). }\end{array}$ & N/A \\
\hline
\end{tabular}

A "snowball" technique was also used to identify other studies not found in the initial desktop research. Some of these were of a "report" rather than academic nature, and this is clearly described in the presentation of the results. These studies were then read, and the observations about the number of jobs were extracted.

It could be argued that the reports should not even be considered in this study. If we would have decided to drop the research or policy reports for this purpose, we would follow any of the PRISMA guidelines/DFID method/Peer Review Quality Index/RDD Method/Consort checklist/AMSTAR Approach. However, considering that there is such a limited number of available per-reviewed papers, we have decided to separately present the non-peer-reviewed papers and draw limited and careful inference on the comparison.

The remainder of the paper is organized as follows. Section 2 introduces the subject of job creation due to wind power, with an emphasize on different types of jobs, and methods and approaches in previous research that has investigated the issue. Section 3 provides a description of the findings in previous studies, whilst Section 4 reports on the results of our assessment. Section 5 synthesizes the empirical findings and discusses the results. Section 6 contains the conclusions and policy implications.

\section{Previous Methods, Models, and Definitions}

In this section, three conceptual topics that are important for the paper are presented and discussed. Specifically, these three concepts are (a) different definitions of jobs that have been used in previous 
papers; (b) methods and approaches to creating the variable of interest; and (c) models to estimate jobs that have been used, commented on in more detail, here, with reference to relevant research done in the wind-energy sector.

\subsection{Definitions of Jobs}

We separated direct and indirect jobs. The International Renewable Energy Agency [12] provides a clear and operational definition of these terms, but also elaborates on important variations in their interpretation across studies it has covered. For direct jobs, manufacturing of key components, power plant construction, and operation and maintenance (O\&M) are generally considered [11]. A problem is that the definitions of direct and indirect (also in some cases induced) jobs vary extensively among the studies [27]. In some cases, planning and project management, research and development, energy companies, utilities, banks, and other services are also included. Indirect jobs have an even more ambiguous definition, where some authors estimate, by input-output analysis (IOA), the indirect effects of materials (e.g., cast iron and steel) and services consumed on the upstream supply chain. These are jobs related to the supply and support of the wind-power industry at a secondary level. A further extension is the consideration of consultancies and several minor components not directly related to the sector.

Some studies differentiate between indirect jobs, as discussed above, and induced jobs, which emerge due to spending originating from direct and indirect employment. These induced effects are included in some studies [18,28], but they are absent in most studies. Calculating induced jobs is cumbersome, but conceptualizing them is somewhat easier. Consider the example of a wind-power-industry employee living in a hotel during construction: This housing arrangement contributes to creating demand for staff in the service sector. In practice, the exact amount of induced jobs is regularly problematic to accurately determine, since isolating spillover employment effects of the deployment may be problematic.

\subsection{Methods and Modeling Approaches of Previous Studies}

The traditional approach to normalize jobs created by energy generation technologies is by generating ratios of jobs created per installed capacity. The calculation is represented by Equation (1):

$$
\text { Index of direct jobs }=\sum \frac{\text { employment in wind power }}{\text { installed capacity }}
$$

Hence, the employment index, expressed in jobs/MW or normalized to job years/MW, is the ratio between jobs created and output added. The index measure is crude and can be criticized. A national index of direct jobs does not assess the employment effects of the whole economy; for example, turbine exports are naturally not installed in the country and hence not counted [29]. Any study comparison must be performed with caution, as a large export industry can lead to peculiar results when assessing jobs per MW. Simas and Pacca [1] showcased Denmark in 2007, where 3 MW of installed wind power led to a value of 7.833 jobs per MW.

There are two main methods used for studying employment effects from wind-farm establishments: the input/output analysis (IOA) and the analytical analysis. The IOA and analytical analysis are both used with a variety of models, leading to different conclusions and results. IOA models capture the whole economy, while analytical models (e.g., survey) fail to capture all employment effects that arise as indirect or induced jobs.

IOA is a "top-down" model that assesses the whole economy, with interactions of services and goods between different industries and consumers. In contrast, the analytical model is a "bottom-up" model. Analytical models can take various shapes where some studies have used secondary data from earlier studies [27] and others have used a survey approach [13].

Both approaches have strengths and weaknesses [30]. Analytical models are a bit easier to comprehend, while also being superior to the IOA for studies on a microlevel. However, the IOA is superior when calculating the job/MW by wind farms over their lifecycles, as it enables assessments of 
both indirect and direct effects. The IOA enables the inclusion and control for other important variables (e.g., environmental or economic impacts) [17].

Here, we shortly present and explain models that are prominent in the studies covered in this literature review:

- rAps [28].

A regional impact assessment model developed by the Swedish Agency for Economic and Regional Growth. The model is based on IOA and aims to covers regional impact analysis, policies, and long-term projections [28]. For other regional impact assessment models, see Okkonen and Lehtonen [15]; Kahouli and Martin [18]; and Jenniches, Worrell, and Fumagalli, [31].

- PANTA RHEI [32,33].

PANTA RHEI is identified as an I/O-based model and is an extension of the econometric model INFORGE. INFORGE is used for econometric simulations/forecasting and covers 59 sectors. PANTA RHEI includes 30 fuels, which cover both usage from household and industry, making PANTA RHEI an ecological extension of the INFORGE model.

- JEDI [16,34].

JEDI (Jobs and Economic Development Impact) is, like rAps and PANTA RHEI, an I/O-based model. JEDI was developed by the National Renewable Energy Laboratory (NREL). The JEDI model is often used for estimations of economic effects originating from specific projects.

- Leontief inverse matrix $[35,36]$.

A Leontief inverse matrix is used for the construction of disaggregated multipliers, which can be used for estimations of direct, indirect, and induced impacts of a specific policy or project. There are two types of the Leontief inverse matrix. The first, Type I, only includes economic sectors. Type I is also a tool for estimations of indirect effects on the economy. Type II covers the household's consumption effects and is used in combination with Type I, to capture possible induced effects [35].

Furthermore, there are calculable general equilibrium (CGE), and macro-econometric (M-E) models. I-O models are perceived to be more accessible than CGE and M-E models [18]. Some other approaches have been without formal modeling, either with literature reviews (much like this one) and by sending out surveys to firms in the sector:

- Literature review $[14,26,37,38]$.

Literature reviews are used for estimating effects of possible outcomes in the economy. By finding studies that have similar scenarios as the one being investigated, it is possible to use results from earlier studies as estimators for the actual study being executed. In the study by Van der Zwaan et al. [37], they combine the results from 22 different publications and use the employment factors to estimate possible employment outcomes for their scenario in the Middle East.

- Surveys $[1,39]$.

Surveys are used in some of the earlier literature. Surveys only give information that the companies surveyed are willing to give, and, therefore, it is possible to lose some information in the process. It is also important to understand that it is impossible to catch all indirect or induced effects by only using surveys. In the article by Simas and Pacca [1], they combine the survey with a literature review and a constructed employment index, to widen the data beyond survey data.

\section{Employment Assessment in Wind-Power-Energy Technologies-A Review of Previous Studies}

In order to construct an outline for the literature synthesis, we organized this research into the following categories: (a) journal articles addressing number of jobs per MW; and (b) non-academic reports. The review is summarized in Tables 1 and 2. There appears to be noticeable variation in the number of jobs, depending on the studies. 


\subsection{Journal Articles}

Most empirical works that are assessing job effects have been concentrated on direct job effects. In several papers, it was argued that measuring and assessing direct jobs was easier than doing so for indirect jobs, which carried a certain portion of insecurity in terms of measurability.

Dvořák et al. [14] examined the Czech Republic's renewable energy sector in terms of ('green') job creation for the period 2008-2013; for wind power, they found that the mean employment effect was 2.3 jobs per MW. In a similar endeavor, Hondo and Moriizumi [17] investigated several renewable energy sources in Japan and found that wind power was expected to totally create 6.48 direct and 10.07 indirect jobs per MW, each year over the project's lifetime; the numbers were derived by the authors of this paper from their estimates by converting their reported numbers that were originally in GWh. Tourkolias and Mirasgedis [35] studied Greece and found that wind-power construction resulted in 8.8 man-years/MW during manufacturing and construction and 0.375 man-years/MW during O\&M. Moreno and López [26] looked at the Spanish region Asturias and estimated that wind-power installation would provide 13.2 job-years/MW in total, of which 13 were in the construction and installation phase. Cai et al. [40] studied Italy over the period 2006-2014 and found that the average total direct and indirect job creation was 10.17 job-years/MW. Jenniches, Worrell, and Fumagalli [31] found a small direct effect, 1.4 jobs/MW in construction phase and $0.3 \mathrm{jobs} / \mathrm{MW}$ in operation phase, and about a three-time larger indirect effect.

Another observation is that the number of jobs can depend on the size of the wind park, mostly due to economies of scale effects [11]. Ejdemo and Söderholm [28] found low job impact per MW from a large park (4000 MW) and assessed that only 0.8 jobs per MW would be added. Okkonen and Lethonen [15] studied a small island-based construction site in Scotland and found that $27 \mathrm{MW}$ would generate around 3 jobs per MW. Kahouli and Martin [18] studied the upcoming installation of 3.5 GW offshore wind installations, which are estimated to lead to job opportunities in the region of Brittany and France, with an estimated 1.32 direct jobs per MW and 1.59 induced jobs per MW.

Blanco and Rodrigues [13] surveyed firms, asking how many jobs their wind-power development led to and found that the result differs widely by country, from 6.97 jobs/MW (Denmark) to 0.76 jobs/MW (Austria). In another article, using a survey, Simas and Pacca [1] found that the job potential in Brazil corresponds to 13.5 persons-year equivalent for each MW installed between manufacture and first year of operation of a wind power plant, and 24.5 persons-year equivalent over the wind farm lifetime. In a study over the job development in the EU tied to wind power Blanco and Kjaer [30] found that 10 jobs/annual MW was created by the manufacturing, construction and installation phase, out of which five jobs/annual MW were in manufacturing.

In the short-term, we will observe both job creation, non-results, and losses in directly affected industries. Jobs will be lost in carbon-intensive sectors, for which growth rate might slow down and eventually even contract (for example, when coal-fired power plants are decommissioned). New jobs will be created in low-carbon sectors (for example, to construct and operate a wind farm).

One important observation is presented in Kattumuri and Kruse [41], who transformed their findings from a project in India to a USA job-intensity level. The labor intensity is rather different between the USA and India, and hence they show that we can expect a larger employment effect in a country with greater labor intensity. 
Table 2. Content summary of reviewed articles.

\begin{tabular}{|c|c|c|c|c|}
\hline Study & Case, Method, and Period & Results & Direct Jobs & Indirect Jobs \\
\hline Moreno and López [26]. & $\begin{array}{l}\text { Spain, Asturias, analytical } \\
\text { model (literature review), } \\
\text { 2005-2010. }\end{array}$ & $\begin{array}{l}\text { The Renewable Energy Development } \\
\text { Plan } 2000-2010 \text { sets policies to reach the } \\
\text { point where } 29.4 \% \text { of generated electricity } \\
\text { comes from renewable energy sources in } \\
\text { the domestic market. This will affect } \\
\text { Spain as a country but also principality } \\
\text { Asturias. }\end{array}$ & $\begin{array}{l}13.2 \text { job-years/MW. } \\
13 \text { job-years/MW in construction } \\
\text { and installation. } \\
0.2 \text { job-years/MW in O\&M. }\end{array}$ & $\mathrm{N} / \mathrm{A}$ \\
\hline Pollin and Garret-Peltier [42]. & $\begin{array}{l}\text { USA, Ontario, I/O-Analysis, } \\
\text { 2008-2017, } 10 \text { years. }\end{array}$ & $\begin{array}{l}\text { The introduction of Green Energy Act by } \\
\text { the government of Ontario led to the start } \\
\text { of an Integrated Power System Plan } \\
\text { (IPSP) where investing would be done in } \\
\text { six different areas for } 10 \text { years. }\end{array}$ & $\begin{array}{l}\text { Onshore wind } 7.6 \text { jobs } / \$ 1 \\
\text { million spent. Offshore wind } 7.6 \\
\text { jobs } \$ 1 \text { million spent. } \\
\text { Onshore wind is expected to } \\
\text { generate } 3400 \text { direct jobs in the } \\
\text { baseline scenario. }\end{array}$ & $\begin{array}{l}\text { Onshore wind } 7.1 \text { jobs } / \$ 1 \\
\text { million spent. Offshore wind } 8.2 \\
\text { jobs/ } \$ 1 \text { million spent. } \\
\text { Onshore wind is expected to } \\
\text { generate } 3204 \text { indirect jobs in } \\
\text { the baseline scenario. }\end{array}$ \\
\hline Blanco and Rodrigues [13]. & $\begin{array}{l}\text { EU, survey and I/O-analysis, } \\
2008 .\end{array}$ & $\begin{array}{l}\text { The expansion of the wind energy is } \\
\text { expected to have resulted in positive } \\
\text { employment effects throughout the EU. } \\
\text { By using a survey and I/O-analysis the } \\
\text { goal was to estimate the amount of direct } \\
\text { jobs originating from the wind energy } \\
\text { sector. }\end{array}$ & $\begin{array}{l}\text { Result differs widely. From } 6.97 \\
\text { jobs/MW (Denmark) to } 0.76 \\
\text { jobs/MW (Austria). }\end{array}$ & $\mathrm{N} / \mathrm{A}$ \\
\hline $\begin{array}{l}\text { Llera, Aranda, Zabalza, and } \\
\text { Scarpellini [43]. }\end{array}$ & $\begin{array}{l}\text { Spain, Pilot case based on a } \\
\text { questionnaire to firms in a } \\
\text { Spanish region, } 2007 .\end{array}$ & $\begin{array}{l}\text { For the energy structure of Aragon, } \\
\text { renewable energy generates between } 4 \\
\text { and } 1.8 \text { times more jobs per MW installed } \\
\text { than conventional sources. }\end{array}$ & 0.86 jobs/MW & $\mathrm{N} / \mathrm{A}$ \\
\hline Tourkolias and Mirasgedis [35]. & $\begin{array}{l}\text { Greece, I/O-analysis (Leontief } \\
\text { inverse matrix), 2011-2020. }\end{array}$ & $\begin{array}{l}\text { The national target for the Greece energy } \\
\text { sector is that the amount of renewable } \\
\text { energy sources would amount to } 40 \% \text { of } \\
\text { total energy production. } \\
\text { The research results showed a induced } \\
\text { effect of } 2.5 \text { man-years/MW. }\end{array}$ & $\begin{array}{l}8.8 \text { man-years/MW during } \\
\text { manufacturing and construction. } \\
0.375 \text { man-years/MW during } \\
\text { O\&M. }\end{array}$ & 3.3 man-years/MW \\
\hline
\end{tabular}


Table 2. Cont.

\begin{tabular}{|c|c|c|c|c|}
\hline Study & Case, Method, and Period & Results & Direct Jobs & Indirect Jobs \\
\hline Bilgili, Yasar, and Simsek [20]. & $\begin{array}{l}\text { Europe, compares investment } \\
\text { costs, employment, industry } \\
\text { and installation between } \\
\text { onshore and offshore wind } \\
\text { power, 2007-2030. }\end{array}$ & $\begin{array}{l}\text { In the study, it was estimated that wind } \\
\text { energy employment will go from } 154,000 \\
\text { jobs in } 2007 \text { to nearly } 330,000 \text { jobs in } 2020 \text {. } \\
\text { It was also expected that offshore } \\
\text { employment will be larger than onshore } \\
\text { employment by the year } 2025 \text {. } \\
\text { Employment was assumed to reach } \\
375.000 \text { by } 2030 \text {. }\end{array}$ & $\mathrm{N} / \mathrm{A}$ & $\mathrm{N} / \mathrm{A}$ \\
\hline $\begin{array}{l}\text { Brown, Pender, Wiser, Lantz, } \\
\text { and Hoen [44]. }\end{array}$ & $\begin{array}{l}\text { USA, county-level, ex-ante } \\
\text { econometric analysis, 2000-2008 }\end{array}$ & $\begin{array}{l}\text { The amount of installed wind energy has } \\
\text { increased in the USA reaching } \\
\text { approximately } 10 \% \text { of total energy } \\
\text { generation in some states. } \\
\text { Total job development was calculated to } \\
\text { be } 0.5 \text { jobs/MW. }\end{array}$ & $\mathrm{N} / \mathrm{A}$ & $\mathrm{N} / \mathrm{A}$ \\
\hline $\begin{array}{l}\text { Van der Zwaan, Cameron, and } \\
\text { Kober [37]. }\end{array}$ & $\begin{array}{l}\text { Literature review on solar and } \\
\text { wind power, 2002-2014, } 70 \\
\text { studies. }\end{array}$ & $\begin{array}{l}\text { The authors observed significant } \\
\text { uncertainties in quoted figures for job } \\
\text { creation, both across and within } \\
\text { publications. }\end{array}$ & 15.6 to 2.7 person-years/MW & $\mathrm{N} / \mathrm{A}$ \\
\hline Simas and Pacca [1]. & $\begin{array}{l}\text { Brazil, survey approach. } \\
\text { Projects that are expected to } \\
\text { begin operations in Brazil until } \\
2017 .\end{array}$ & $\begin{array}{l}\text { The job potential in Brazil corresponds to } \\
13.5 \text { persons-year equivalent for each } \\
\text { MW installed between manufacture and } \\
\text { first year of operation of a wind power } \\
\text { plant, and } 24.5 \text { persons-year equivalent } \\
\text { over the wind farm lifetime. }\end{array}$ & 10.74 person-years/MW. & 2.79 person-years/MW. \\
\hline $\begin{array}{l}\text { Pollin, Garret-Peltier, Heintz, } \\
\text { and Hendricks [45]. }\end{array}$ & USA, I/O-analysis, 2015-2030. & $\begin{array}{l}\text { The Intergovernmental Panel on Climate } \\
\text { Change proposed that the world should } \\
\text { reduce its greenhouse gas emissions by } \\
40 \% \text { from } 2005 \text { to } 2035 \text {. For the USA to do } \\
\text { its part, it would need to reduce the C } 02 \\
\text { emissions from USA energy-based } \\
\text { sources by } 40 \% \text {. This will according to } \\
\text { Pollin et al. generate jobs in the process. } \\
\text { In addition to the direct and indirect jobs } \\
3.6 \text { induced jobs } \$ 1 \text { million spent and an } \\
\text { additional } 1.6 \text { induced jobs } \$ 1 \text { million } \\
\text { spent in O\&M making it a total of } 5.2 \\
\text { induced jobs } \$ 1 \text { million spent. }\end{array}$ & $\begin{array}{l}\text { Onshore wind would generate } \\
4.7 \text { direct jobs } \$ 1 \text { million spent. } \\
1.5 \text { direct jobs } / \$ 1 \text { million spent } \\
\text { in O\&M. } \\
\text { A total of } 5.2 \text { direct jobs } / \$ 1 \\
\text { million spent. }\end{array}$ & $\begin{array}{l}\text { Onshore wind would generate } \\
4.4 \text { indirect jobs } / \$ 1 \text { million spent } \\
2.4 \text { indirect jobs } / \$ 1 \text { million spent } \\
\text { in O\&M. } \\
\text { A total of } 6.8 \text { indirect jobs } / \$ 1 \\
\text { million spent. }\end{array}$ \\
\hline
\end{tabular}


Table 2. Cont.

\begin{tabular}{|c|c|c|c|c|}
\hline Study & Case, Method, and Period & Results & Direct Jobs & Indirect Jobs \\
\hline Ejdemo and Söderholm [28]. & $\begin{array}{l}\text { Sweden, Markbyggden. } \\
\text { Regional impact model rAps, } \\
\text { 2012-2019. }\end{array}$ & $4000 \mathrm{MW}$ project with 0.8 jobs per MW. & $\begin{array}{l}450 \text { during construction. } \\
426 \text { during construction and } 50 \\
\text { during O\&M. }\end{array}$ & $\begin{array}{l}50 \text { maintenance, } \\
95 \text { during construction, and } 20 \\
\text { induced and indirect during } \\
\text { maintenance. }\end{array}$ \\
\hline Walwyn and Brent [46]. & South Africa, 2011-2013 & $\begin{array}{l}\text { South Africa has introduced a program } \\
\text { called Renewable Energy Independent } \\
\text { Power Producers Procurement } \\
\text { Programme (or REI4P for short). The } \\
\text { initiative from the program is to install } \\
17.8 \text { GW of renewable energy sources. }\end{array}$ & $\begin{array}{l}\text { Results are differentiated in } 3 \\
\text { different rounds, where the first } \\
\text { round resulted in } 3.9 \text { operation } \\
\text { jobs/MW, round two resulted in } \\
4.0 \text { operation jobs/MW, and the } \\
\text { third round resulted in } 10.8 \\
\text { operation jobs/MW. During } \\
\text { these three rounds, a total of } \\
19,414 \text { jobs were created in } \\
\text { operation and construction. }\end{array}$ & $\mathrm{N} / \mathrm{A}$ \\
\hline Okkonen and Lethonen [15]. & $\begin{array}{l}\text { Northern Scotland, regional } \\
\text { I/O-analysis. } \\
11 \text { wind farms of } \\
\text { community-based social } \\
\text { enterprises located in the Outer } \\
\text { Hebrides, Shetland, and Orkney. } \\
\text { Project constructed before } 2016\end{array}$ & $\begin{array}{l}\text { Socioeconomic analyses find that } \\
\text { community-based social enterprises are } \\
\text { one promising solution for place-based } \\
\text { regional development in the European } \\
\text { northern periphery. }\end{array}$ & $\begin{array}{l}70.3 \text { construction job and } \\
10 \text { operation and maintenance } \\
\text { jobs on } 27 \mathrm{MW} .\end{array}$ & N/A \\
\hline $\begin{array}{l}\text { Cai, Cusumano, Lorenzoni, and } \\
\text { Pontoni [40]. }\end{array}$ & $\begin{array}{l}\text { Italy, combines an input-output } \\
\text { approach with a com- } \\
\text { prehensive bottom-up analytical } \\
\text { model, 2006-2014. }\end{array}$ & $\begin{array}{l}\text { In net terms, installation of new wind } \\
\text { plants generated fewer jobs than } \\
\text { alternative uses of the same resources. }\end{array}$ & $\begin{array}{l}\text { Construction, installation, and } \\
\text { maintenance: } 9.9 \\
\text { person-years/MW. } \\
\text { Operation and maintenance: } \\
0.27 \text {. }\end{array}$ & $\mathrm{N} / \mathrm{A}$ \\
\hline
\end{tabular}


Table 2. Cont.

\begin{tabular}{|c|c|c|c|c|}
\hline Study & Case, Method, and Period & Results & Direct Jobs & Indirect Jobs \\
\hline Hondo and Moriizumi [17]. & $\begin{array}{l}\text { Japan, I/O-analysis. Lifecycle of } \\
20 \text { years. }\end{array}$ & $\begin{array}{l}\text { The expected employment from wind } \\
\text { energy will be } 8.23 \text { job-years/MW during } \\
\text { construction }(2.1 \text { direct }+6.13 \text { indirect } \\
\text { during construction) and } 8.32 \text { during } \\
\text { O\&M ( } 4.38 \text { direct }+3.94 \text { indirect during } \\
\text { O\&M). }\end{array}$ & $\begin{array}{l}2.1 \text { job-years/MW during } \\
\text { construction }+4.38 \text { during } \\
\mathrm{O} \& \mathrm{M}=6.48\end{array}$ & $\begin{array}{l}\text { 6.13 job-years/MW during } \\
\text { construction }+3.94 \\
\text { job-years/MW during O\&M = } \\
10.07\end{array}$ \\
\hline $\begin{array}{l}\text { Dvořák, Martinát, Van der } \\
\text { Horst, Frantal, and } \\
\text { Turečková [14]. }\end{array}$ & $\begin{array}{l}\text { Czech Republic, analytical } \\
\text { approach with policy document } \\
\text { analysis and descriptive } \\
\text { statistics (literature review for } \\
\text { benchmarking), 2008-2013. }\end{array}$ & $\begin{array}{l}\text { As the environmental policies are } \\
\text { pushing the development of renewable } \\
\text { energy sources, the push leads to new job } \\
\text { opportunities in the new energy sectors. }\end{array}$ & $\begin{array}{l}\text { Maximum: } 4 \text { jobs/MW. } \\
\text { Minimum: } 0.9 \text { jobs/MW. } \\
\text { Mean: } 2.3 \text { jobs/MW. }\end{array}$ & $\mathrm{N} / \mathrm{A}$ \\
\hline Kattumuri and Kruse [41]. & $\begin{array}{l}\text { India, Karnataka, case studies } \\
\text { with interviews, 2015-2016 }\end{array}$ & $\begin{array}{l}\text { Labor intensity between countries } \\
\text { matters; when the Indian results are } \\
\text { translated to USA figures, the } \\
\text { employment effect goes down. Based on } \\
\text { Karnataka-specific employment factors, } \\
\text { they found a potential of } 26,000 \text { jobs in } \\
\text { wind energy, of which } \\
12,000 \text { were skilled and } 14,000 \text { unskilled } \\
\text { jobs. }\end{array}$ & $\begin{array}{l}13.98 \text { jobs/MW (USA job factor } \\
=0.79-2.79)\end{array}$ & $\mathrm{N} / \mathrm{A}$ \\
\hline Kahouli and Martin [18]. & $\begin{array}{l}\text { France, Brittany and national, } \\
\text { I/O-analysis, 2016-2040. }\end{array}$ & $\begin{array}{l}\text { France has } 3.5 \mathrm{GW} \text { of offshore wind } \\
\text { installations in the pipeline, which is } \\
\text { estimated to lead to job opportunities in } \\
\text { the region of Brittany and France as a } \\
\text { whole. }\end{array}$ & $\begin{array}{l}1919 \text { during construction and } \\
200 \text { during O\&M in Brittany. } \\
3277 \text { during construction and } \\
200 \text { during O\&M in France. } \\
6.03 \text { jobs/MW in investment } \\
\text { phase. } \\
1.02 \text { jobs/MW in O\&M. }\end{array}$ & $\begin{array}{l}460 \text { during construction and } 153 \\
\text { during O\&M in Brittany. } \\
2874 \text { during construction and } \\
357 \text { during maintenance in } \\
\text { France. }\end{array}$ \\
\hline $\begin{array}{l}\text { Mu, Cai, Evans, Wang, and } \\
\text { Roland-Host [47]. }\end{array}$ & $\begin{array}{l}\text { China. a computable general } \\
\text { equilibrium (CGE) model. } 2012 .\end{array}$ & $\begin{array}{l}\text { There was job creation from both wind } \\
\text { and solar power, but sometimes a net } \\
\text { negative job effect. }\end{array}$ & 1 jobs/MW & 15.7 jobs/MW \\
\hline $\begin{array}{l}\text { Jenniches, Worrell, and } \\
\text { Fumagalli [31]. }\end{array}$ & $\begin{array}{l}\text { Germany, small region of } \\
\text { Aachen, 2017-2035. }\end{array}$ & $\begin{array}{l}\text { The authors use a supply chain analysis } \\
\text { to study a } 63.1 \mathrm{MW} \text { project. }\end{array}$ & $\begin{array}{l}1.4 \text { jobs/MW in construction } \\
\text { phase and } 0.3 \text { jobs/MW in } \\
\text { operation phase. }\end{array}$ & 4.9 jobs/MW due to taxes etc. \\
\hline
\end{tabular}


There were also some findings regarding jobs where we could not transform the number of jobs into a Jobs/MW ratio, but they are relevant to mention anyway. Lehr et al. [32] found that overall net employment is positive even at the maximum of the (negative) budget effect. When modeling different scenarios for employment development in Germany in the renewable energy sector, Lehr et al. [33] found that almost all the scenarios exhibit positive net employment effects. Under medium assumptions, net employment associated with the RE expansion would be close to 150,000 in 2030. In the higher scenarios, gross employment will increase from 340,000 in 2009 to between 500,000 and 600,000 in 2030. Previous studies have also found that high investment levels and large capacities installed directly exert a positive effect on employment [32]. The positive effects are to some extent counterbalanced by the reduced investments in for example fossil fuel systems.

The variance between the obtained results in the assessed paper was large. A low (0.5 per MW each year over the project's lifetime) was found in a paper by Brown et al. [44], and the highest (15.6 jobs/MW) finding was by Van der Zwaan, Cameron, and Kober [37].

\subsection{Non-Peer-Reviewed Reports}

Singh and Fehrs [39] showed that investment in wind farms will generate more jobs per $\$ 1$ million dollars investment than coal and photovoltaic power. However, a recent report by Comings et al. [16] concludes that wind farms now generate less work than their photovoltaic counterpart, with a difference of 9 less direct jobs per MW and 46 less indirect/induced jobs per MW. According to Comings et al. [16], wind energy also leads to less O\&M jobs than photovoltaic energy. Maia et al. [38] concluded that South Africa's New Growth Path program would lead to approximately 6.5 direct jobs/MW. Throughout the assessed reports, two measures are used: jobs/MW [16,38] and jobs/\$1 million in spending [42,45].

Mauritzen [48] found the surprising (but plausible) result that there seem to be no job effects in rural counties. Mauritzen argues that it is plausible that skilled labor is employed from outside the county hosting a wind-power plant for both the initial construction and the subsequent maintenance and repairs.

Most of the reports look at onshore wind farms; however, some reports include evaluations of employment effects originating from offshore wind farms [30,42]. Pollin and Garret-Peltier [42] concluded that the Green Energy Investments in Ontario, USA, would produce 7.6 direct jobs $/ \$ 1$ million spent and that offshore wind energy will surpass onshore wind energy in number of total employees by year 2025. For a summery of the paper see Table 3 . 
Table 3. Content summary of reviewed reports.

\begin{tabular}{|c|c|c|c|c|}
\hline Study & Case, Method, and Period & Results & Direct Jobs & Indirect Jobs \\
\hline Singh and Fehrs [39] & USA, survey approach, N/A. & $\begin{array}{l}\text { In the future, the expected job opportunities } \\
\text { arising from the renewable energy sector will be } \\
\text { lower due to atomization. At the same time, it is } \\
\text { apparent that coal energy is in need of less } \\
\text { person-years per MW than both photovoltaic } \\
\text { energy and wind energy. }\end{array}$ & $\begin{array}{l}\text { A total employment effect of } 4.8 \\
\text { person-years/MW. }\end{array}$ & N/A \\
\hline Pembina Institute [49] & $\begin{array}{l}\text { Canada, unknown method, } \\
\text { 2004-2020. }\end{array}$ & $\begin{array}{l}\text { Conclusion of } 13 \text { independent reports and } \\
\text { studies that analyze the economic and } \\
\text { employment impacts of the clean energy } \\
\text { industry in the United States and Europe. }\end{array}$ & $\begin{array}{l}3.92 \text { job-years/MW in manufacturing, } \\
\text { development and construction. } \\
0.10 \text { jobs/MW in O\&M. }\end{array}$ & N/A \\
\hline Kammen, Kapadia, and Fripp [50] & USA, 2004. & N/A & $0.71-2.79$ & N/A \\
\hline McKinsey, [51] (in Wei et al. [27]) & USA, N/A. & N/A & $\begin{array}{l}10.96 \text { job-years/MW in construction, installation, } \\
\text { and manufacturing. } \\
0.18 \text { job-years/MW in O\&M. }\end{array}$ & N/A \\
\hline Blanco and Kjaer [30] & $\begin{array}{l}\text { EU, literature review/analytical, } \\
2007-2030 \text {. }\end{array}$ & $\begin{array}{l}7 \text { years of wind-power developments in EU led } \\
\text { to an } 339 \% \text { increase in capacity and a total } \\
\text { employment of } 154,000 \text { jobs at the end of } 2007 \text {. } \\
\text { The EU is still expanding its renewable energy } \\
\text { sector and the amount of jobs from wind power } \\
\text { are expected grow further. }\end{array}$ & $\begin{array}{l}10 \text { jobs/annual MW for manufacturing, } \\
\text { construction and installation. }\end{array}$ & $\begin{array}{l}5 \text { jobs/annual MW for } \\
\text { manufacturing. }\end{array}$ \\
\hline Maia et al., [38] & $\begin{array}{l}\text { South Africa, analytical model } \\
\text { (literature review), 2011-2025, } \\
\text { divided into three timeframes } \\
\text { (2011-2012, 2013-2017, and } \\
\text { 2018-2025). }\end{array}$ & $\begin{array}{l}\text { As "green economy" got traction the South } \\
\text { African government found interest in the area as } \\
\text { South Africa has an economy that is carbon } \\
\text { intensive. The green economy was therefore } \\
\text { included in the "New Growth Path" strategy } \\
\text { document and was identified as one of the "job } \\
\text { drivers". }\end{array}$ & 6.5 jobs/MW & N/A \\
\hline Steinberg, Porro, and Goldberg [34]. & $\begin{array}{l}\text { USA, I/O analysis (JEDI), } \\
\text { 2009-2011. }\end{array}$ & $\begin{array}{l}\text { After the financial crisis in 2008/2009 the number } \\
\text { of investors in tax equities decreased. The } \\
\text { decrease of investors resulted in the } \$ 1603 \\
\text { Treasury grant program which was aimed to } \\
\text { give renewable energy projects a one-time } \\
\text { payment. Total of 12,827 MW. }\end{array}$ & $\begin{array}{l}16,000 \text { job-years. } \\
1.249 \text { job-years/MW. }\end{array}$ & $\begin{array}{l}\text { 111,000-170,000 } \\
\text { job-years. } \\
\text { Max 13.271 } \\
\text { job-years/MW. } \\
\text { Min 8.665 } \\
\text { job-years/MW. }\end{array}$ \\
\hline
\end{tabular}


Table 3. Cont

\begin{tabular}{|c|c|c|c|c|}
\hline Study & Case, Method, and Period & Results & Direct Jobs & Indirect Jobs \\
\hline $\begin{array}{l}\text { Van der Zwaan, Cameron, and } \\
\text { Kober [37]. }\end{array}$ & $\begin{array}{l}\text { Middle East, analytical model } \\
\text { (literature review), 2012-2050. }\end{array}$ & $\begin{array}{l}\text { The scenario investigated is what the } \\
\text { employment outcomes would be if the Middle } \\
\text { East achieved a renewable energy share of } 60 \% \\
\text { by year } 2050 \text {. }\end{array}$ & $\begin{array}{l}\text { The median result for wind power was that it } \\
\text { would lead to } 8.1 \text { job-years/MW during } \\
\text { manufacturing and installation and } 0.2 \\
\text { job-years/MW during O\&M. } \\
\text { This would lead to approximately } 12,500 \text { jobs in } \\
\text { the wind energy sector year 2050. } \\
\text { Max } 15 \text { person-years/MW in M\&I and } 0.6 \\
\text { person-years/MW in O\&M. } \\
\text { Min 2.6 person-years/MW in M\&I and } 0.1 \\
\text { person-years/MW in O\&M. }\end{array}$ & N/A \\
\hline $\begin{array}{l}\text { Comings, Fields, Takahashi, and } \\
\text { Keith [16]. }\end{array}$ & $\begin{array}{l}\text { USA, Montana, } \mathrm{I} / \mathrm{O} \text { analysis } \\
\text { (JEDI), 2014-2034, an } \\
\text { assessment covering the coming } \\
20 \text { years. }\end{array}$ & $\begin{array}{l}\text { Manufacturing is missed as the report mainly } \\
\text { focus on construction, installation, and O\&M. }\end{array}$ & $\begin{array}{l}6 \text { job-years/MW during construction. } \\
0.4 \text { job-years/MW during O\&M. }\end{array}$ & $\begin{array}{l}8 \text { indirect/induced } \\
\text { job-years/MW during } \\
\text { construction. } \\
0.3 \text { indirect/induced } \\
\text { job-years/MW during } \\
\text { O\&M. }\end{array}$ \\
\hline Garret-Peltier [36]. & USA, $\mathrm{I} / \mathrm{O}$ analysis. & $\begin{array}{l}\text { The study finds that a total average of } 7.52 \\
\text { job-years is created per } \$ 1 \text { million spent looking } \\
\text { at different studies. }\end{array}$ & An average of 4.06 job-years $/ \$ 1$ million spent. & $\begin{array}{l}\text { An average of } 3.46 \\
\text { job-years/ } \$ 1 \text { million } \\
\text { spent. }\end{array}$ \\
\hline Mauritzen [48]. & $\begin{array}{l}\text { USA, Bayesian approach, using } \\
\text { Markov Chain Monte-Carlo } \\
\text { simulations, 2009-2016. }\end{array}$ & $\begin{array}{l}\text { Identifies no significant wind power effect on net } \\
\text { rural employment, but find that on average, a } \\
\text { midsize } 200 \text { MW wind farm leads to a permanent } \\
\text { increase in wages of approximately } 2.5 \text { percent. }\end{array}$ & Rural employment 0 . & $\begin{array}{l}\text { Possibly outside } \\
\text { studied areas. }\end{array}$ \\
\hline
\end{tabular}




\section{Results-Jobs per MW}

In this section, we gather and present the numerical results from the literature reviewed in two tables, Tables 4 and 5 below. The difference between the two tables is that the table for the article includes "min O\&M" and "max induced", while the report table does not. The motivation is that the reports never presented any estimations for either minimum O\&M jobs/MW or maximum induced jobs/MW.

\subsection{Journal Articles}

There is an indication (slight) that the number of employees per installed MW has decreased over time (the number of observations is, however, too low to draw any definite inference). Economic theory would suggest that, as the deployment of a technology expands, the cost should go down [51-53].

It is unclear if choice of methods and definitions in the studies affect the results. If we take an average of the jobs created per MW (with full awareness with the limitations of doing such a thing), 5.68 jobs created per MW under the construction time is revealed in the academic literature. The reports we considered had a slightly higher estimate (5.76). To see if the average value in direct max jobs/MW is not largely affected by the maximum and minimum values, we dropped them to check for robustness. When excluding the maximum and minimum values, the average value fell from 5.68 to 5.32 jobs/MW.

\subsection{Reports}

In the non-journal articles, slightly higher estimates for indirect jobs were found, but the sample is too small to generalize about, as some extreme values drive the results (besides a limited number of studies). In the same approach to the journal articles above, we dropped the maximum and minimum values in direct max jobs/MW. Excluding the maximum and minimum value did not lead to any big alterations in the average jobs/MW, as the average value rose from 5.76 to 5.80 jobs/MW.

It is challenging to draw inference from previous studies in order to make an assessment on an upcoming project. Hence, when comparing studies, factors such as development size, geographical conditions, labor market structure, institutional settings, and time period are just a few of the major issues that will be important when making a job creation assessment. We observed that non-journal articles also indicated slightly higher estimates for direct job effects from wind-farm establishments. 
Table 4. Jobs per MW in journal articles.

\begin{tabular}{|c|c|c|c|c|c|c|c|}
\hline Articles & $\begin{array}{l}\text { Direct Max } \\
\text { (Jobs/MW) }\end{array}$ & $\begin{array}{l}\text { Direct Min } \\
\text { (Jobs/MW) }\end{array}$ & $\begin{array}{c}\text { Indirect } \\
\text { (Jobs/MW) }\end{array}$ & $\begin{array}{c}\text { Total Direct and } \\
\text { Indirect (Jobs/MW) }\end{array}$ & $\begin{array}{l}\text { Max O\&M } \\
\text { (Jobs/MW) }\end{array}$ & $\begin{array}{l}\text { Min O\&M } \\
\text { (Jobs/MW) }\end{array}$ & $\begin{array}{l}\text { Max Induced } \\
\text { (Jobs/MW) }\end{array}$ \\
\hline Moreno and López [26]. & 13.2 & & & & 0.2 & & \\
\hline Blanco and Rodrigues [13]. & $0.76-6.97$ & 0.76 & & & & & \\
\hline Llera, Aranda, Zabalza, and Scarpellini [43]. & 0.86 & & & & & & \\
\hline Tourkolias and Mirasgedis [35]. & 9.175 & & 3.3 & & 0.375 & & \\
\hline Brown, Pender, Wiser, Lantz, and Hoen [44]. & 0.5 & & & & & & \\
\hline Van der Zwaan, Cameron, and Kober [37]. & 15.6 & 2.7 & & & 0.6 & 0.1 & \\
\hline Simas and Pacca [1]. & 10.74 & & 2.79 & & & & \\
\hline Ejdemo and Söderholm [28]. & 0.8 & & & & & & \\
\hline Walwyn and Brent [46]. & & & & & 10.8 & 3.9 & \\
\hline Okkonen and Lethonen [15]. & 3 & & & & & & \\
\hline Hondo and Moriizumi [17] * & 6.48 & & 10.07 & 16.55 & 8.32 & & \\
\hline Cai, Cusumano, Lorenzoni, and Pontoni [40]. & & & & 10.17 & & & \\
\hline $\begin{array}{l}\text { Dvořák, Martinát, Van der Horst, Frantal, and } \\
\text { Turečková [14]. }\end{array}$ & 4 & 0.9 & & & & & \\
\hline Kattumuri and Kruse [41]. & 13.98 India (USA 2.79). & USA 0.79 & & & & & \\
\hline Kahouli and Martin [18]. & 1.32 & & 1.226 & & 0.4 & & 1.59 \\
\hline Mu, Cai, Evans, Wang, and Roland-Host [47]. & 1 & & 15.7 & & & & -16.7 and -2.2 \\
\hline Jenniches, Worrell, and Fumagalli [31]. & $0.3-1.4$ jobs/ & 4.9 & & 5.2 & & & \\
\hline Range & $0.5-15.6$ & $0.9-2.7$ & $1.22-15.7$ & $5.2-16.55$ & $0.2-10.8$ & $0.1-3.9$ & -16.2 to 1.59 \\
\hline Average & 5.68 & 2.35 & 6.61 & 10.64 & 3.44 & 2 & 1.59 \\
\hline
\end{tabular}

Notes: ${ }^{*}=$ over lifetime, and they use an IO model they constructed themselves; numbers derived by the authors of this paper from their estimates by converting their reported numbers that were originally in GWh 
Table 5. Jobs per MW in reports.

\begin{tabular}{|c|c|c|c|c|c|}
\hline Reports & Direct Max (Jobs/MW) & Direct Min (Jobs/MW) & Max Indirect (Jobs/MW) & Min Indirect (Jobs/MW) & Max O\&M (Jobs/MW) \\
\hline Singh and Fehrs [39]. & 4.8 & & & & \\
\hline Pembina Institute, [49]. & 3.92 & & & & \\
\hline Kammen, Kapadia, and Fripp [50]. & $0.71-2.79$ & 0.71 & & & \\
\hline McKinsey [51] (in Wei et al. [27]). & 11.14 & & & & 0.18 \\
\hline Blanco and Kjaer [30]. & 10 & & 5 & & \\
\hline Pollin and Garret-Peltier [42]. & 10.768 & 8 & 10.059 & 7.428 & \\
\hline Maia et al., [38]. & 6.5 & & & & \\
\hline Steinberg, Porro, and Goldberg, [34]. & 1.249 & & 13.271 & 8.665 & \\
\hline Comings, Fields, Takahashi, and Keith [16]. & 6.4 & & 8.3 & & 0.4 \\
\hline Mauritzen [48]. & 0 & & & & \\
\hline Range & $0-11.14$ & $0.71-8$ & $5-13.271$ & $7.428-8.665$ & $0.18-0.4$ \\
\hline Average & 5.76 & 4.355 & 9.16 & 8.05 & 0.29 \\
\hline
\end{tabular}




\section{Discussion}

\section{A Result-Oriented Discussion}

The results in the reviewed studies were varied, creating a challenge for any policy maker who want to draw conclusions. One challenge connected to the assessment of job effects from wind power is that the information's relevance depends on the context from where it originates, and the results vary largely, due to methodological approaches.

The first objective we outlined in the introduction was to provide an extended review of the literature into the modern age. We noticed that there seems to be an increasing amount of papers and reports, from one or no paper per year in the beginning of this decade to a steadier stream with more than one paper per year in the end of our period. The increasing amount of writing indicates that the issue has become more prioritized by researchers, which make sense, considering the large expansion of installed wind power cumulative capacity.

Regarding the second objective, to outline the different modeling approaches, we found some important insights. Estimation and modeling choices also matter, and we have presented several different estimation approaches. As we described in Section 2.2, there are several approaches and models to use when looking at job creation. The main categories were IOA and analytical analysis, and different used models consisted of rAps, PANTA RHEI, JEDI, Leontief inverse matrix, literature review, and Surveys. Our own assembled data material is too small to comment in any significant way on which model creates the larger or smaller estimates, but we can at least notice that there are several ways to make the estimations.

For the third objective, we wanted to establish a span of the job creation. The span was between 0.5 and 15.6 when it came to direct job creation. One observation is that there are several ways to consider job creation, and we found several in the literature. Besides the "Maximum of direct jobs", we also were able to catalogue direct minimum (range 0.9-2.7; average 2.35), indirect jobs (range 1.22-15.7; average 6.61), total direct and indirect (Range 5.2-16.55, average 10.64), max O\&M (operation and management; range 0.2-10.8; average 3.44), min O\&M (range 0.1-3.9; average 2), and max induced jobs (range 0.9-2.7; average 2.35). Hence, job creation will also be dependent on how you choose to look at the creation and what jobs you consider. To ensure consistency when comparing different project, methods used for data collection, interpretations obtained from employment ratios, territory aspects, development speed of technologies, maturity of industry, and availability of skilled labor (to name a few) must be considered [43]. Some other factors that hinder a comparison are return-to-scale factors, geographical distances, labor-cost differences, and institutional factors. Thus, any obtained results are hardly comparable or applicable to contexts outside wind power and should be interpreted with caution on a country level.

Size matters, even when it comes to wind power projects. For example, Ejdemo and Söderholm [28] found a very small direct job effect when they investigated the Swedish Markbygden wind-power project, with 1101 windmills (4GW) planned to be constructed over the period 2012-2019, making it possibly the largest onshore wind farm in Europe. On the other end, we had, for example Okkonen and Lethonen [15], who studied a small island-based construction in Scotland and found that, at $27 \mathrm{MW}$, this project electricity generation would not be a 1000th of the Markbygden size, and hence we saw more jobs (3) per MW.

Explanations for the big discrepancy, as seen, between the Markbygden and Scottish example in the paragraph above can be found in economic concepts such as economies-of-scale and learning-by-doing, which will theoretically influence job creation in a project. Economies-of-scale can reduce labor intensity per unit of installed MW in larger projects. For example, if a firm constructs 100 wind-power plants, a certain number of employees will be needed. If 10 more are added during the process, the labor force is not likely to grow by 10 percent; some positions will, but the firm will not hire 0.1 extra CEOs. More specifically, considering learning-by-doing, two projects of the same size that are done two 
decades apart will need a different number of workers; the later project would be expected to need fewer workers $[11,37,54,55]$.

As we saw in a paper concerning India, labor intensity matters [41]. This is an indication that cross-country comparability is hard and, in some cases, not fruitful. If a policy maker should do a cross-country comparison, then it is important that the country selection is based on matched pairs, not just data availability.

Pursuing multiple policy targets (low unemployment and expansion of renewable energy) is a questionable strategy. Environmental externalities, such as anthropogenic greenhouse gas emissions, are most effectively targeted through Pigouvian emission taxes-additional targets for renewable energy are either redundant or costly [56]. If, however, a policy maker pursues several targets, efficient regulation calls for an equalization of the number of policy instruments with the number of policy targets [57].

There is a potential trade-off between economic efficiency and labor market effects. It could be the case that even with a net growth in jobs, general welfare can be reduced due to unintended production alterations generated by renewable energy subsidies. Böhringer et al. [57] show that initial labor-market rigidities have a potential, in theory, to provide some scope for such a double dividend in terms of positive labor market effects derived from government subsides, but also find that the practical outcome of renewable energy promotion might be sobering. There are counteracting factors for the expansion of labor in the renewable energy sector. Dynamic effects of a changing economic structure and of technological change play a part such as that increasing productivity can increase output with the same level of employment. General factors, such as budget effects on household incomes or reduced imports of fossil fuels and other goods, should also be considered [32].

The road to hell is paved with good intentions, and standard economic theory warns against the thought of a magic cure through any (including renewable) promotion policies that will lead to an unambiguous win-win outcome. There will be both winners and losers as the world moves toward a low-carbon economy $[13,58,59]$.

Regarding winners and losers, there is a public expectation of a short-term jobs shift from high-carbon activities to low-carbon activities [27,32,57-59]. Where a net effect could be job creation based on the notion that low-carbon jobs are more labor intensive and an economy-transforming wave of 'creative destruction' is often associated with innovation, job creation, and growth [55,60-63], and also opportunity for rural development $[15,28]$. Hence, when it comes to the job issue, we can expect some instances of significant job growth but also some local, classical Schumpeterian constructive destruction.

\section{Concluding Remarks and Directions for Future Research}

The purpose of this paper was to provide a global overview of job effects per MW of wind-power installations, which will enable improved decision making and modeling of future wind-power projects. Papers from 2001 to 2019 were reviewed. Previously, there was a lack of comprehensive reviews of the subject, something this paper has remedied by assembling the research that has been done so far. It should be noted that the different wind-power projects assessed in this paper are heterogeneous in nature and previous studies cover small and large wind-power cases. The large expansion of wind power has occurred during the last decade, which also affects the number of studies that have been performed. Several studies are probably coming in the near future as more and more projects are finalized. We confirm the general notion that job creation in wind-power installation is somewhat limited.

How should a policy maker think about the large difference between different projects? If the policy makers adopt a time-consistent approach where they expect that several projects will be done in a region or a country, then they cannot overpromise and under-deliver. For example, if the inhabitants in a region are promised a certain amount of economic benefits in terms of jobs when they give up natural values such as a landscape with a picturesque view, then any failure in living up to the initial 
promise will create future problems. One future problem is lack of legitimacy and a NIMBYism that can slow down or even derail future projects. Hence, the policy maker should try to estimate the coming project with information to projects that have some degree of similarities regarding time, size, installed equipment, and general institutional settings.

The major policy conclusion that follows is that a policy maker should consider asking for separate assessments of each project, since applying averages from old wind-power projects to get an estimate of job creation will not give good guidelines. The need for extra consideration assumes a need for accuracy. Accuracy is of course not always needed, and there is a case to be made that the policy maker should consider the cost benefit of getting this separate analysis.

Factors that hinder a side-by-side comparison are (to name a few) return-to-scale factors, geographical distances, labor cost differences, and institutional factors. Moreover, any future study must also be careful to ensure consistency in terms of methods used for data collection, assumptions about development speed of technologies, maturity of industry, and availability of skilled labor. The following summarizes the main points we have learned:

- Job numbers will not be time consistent-the same-sized project will need a different amount of labor if they are constructed a decade apart.

- Project scale effect will affect the numbers of jobs created with a possible decreasing return to scale effect.

- The labor intensity and institutional arrangements in the country will affect the amount of jobs created.

There are several ways to improve the analysis carried out in this paper if newer data could be obtained or older projects would be evaluated consistently with jobs/MW. Outstanding questions include the following: How much would the estimated average job counts vary if we managed to find more studies? Venues for further research include the area of offshore wind energy, as it is expected to reach a higher total employment than onshore wind farms. Further research should also be cautious of comparing jobs/MW if it does not have the same prerequisites as earlier studies.

Author Contributions: L.A. and C.P.V. developed Sections 1, 5 and 6. J.G. and K.S. wrote Sections 2-4. All authors have read and agreed to the published version of the manuscript.

Funding: This research received no external funding.

Acknowledgments: This research did not receive any specific grant from funding agencies in the public, commercial, or not-for-profit sectors. The authors would like to extend a special thanks to the reviewers of this paper that had a good eye for details and many constructive suggestions.

Conflicts of Interest: The authors declare no conflicts of interest.

\section{References}

1. Simas, M.; Pacca, S. Assessing employment in renewable energy technologies: A case study for wind power in Brazil. Renew. Sustain. Energy Rev. 2014, 31, 83-90. [CrossRef]

2. Fankhaeser, S.; Sehlleier, F.; Stern, N. Climate change, innovation and jobs. Clim. Policy 2008, 8, 421-429. [CrossRef]

3. Apergis, N.; Payne, J.E. Renewable energy consumption and economic growth: Evidence from a panel of OECD countries. Energy Policy 2010, 38, 656-660. [CrossRef]

4. Mathiesen, B.V.; Lund, H.; Karlsson, K. 100\% renewable energy systems, climate mitigation and economic growth. Appl. Energy 2011, 88, 488-501. [CrossRef]

5. Chen, M.J. Job versus environment: An examination on the attitude of union members toward environmental spending. Environ. Econ. Policy Stud. 2017, 19, 761-788. [CrossRef]

6. Intergovernmental Panel on Climate Change (IPCC). Climate Change 2007: The Physical Science Basis, Contribution of Working Group i to the Fourth Assessment, Report of the Inter-Governmental Panel on Climate Change; IPCC: Geneva, Switzerland, 2007. 
7. Intergovernmental Panel on Climate Change (IPCC). Climate Change 2013: The Physical Science Basis, Contribution of Working Group i to the Fifth Assessment, Report of the Inter-Governmental Panel on Climate Change; IPCC: Geneva, Switzerland, 2013.

8. Stern, N. The Economics of Climate Change: The Stern Review; Cambridge University Press: New York, NY, USA, 2007.

9. World Wind Energy Association (WWEA). Wind Power Capacity Reaches 539 GW, 52,6 GW Added in 2017. 2018. Available online: https://wwindea.org/blog/2018/02/12/2017-statistics/ (accessed on 20 September 2018).

10. European Union. Directive 2009/28/EC of the European Parliament and of the Council of 23 April 2009 on the promotion of the use of energy from renewable sources and amending and subsequently repealing Directives 2001/77/EC and 2003/30/EC. Off. J. Eur. Union 2009, 5, 62.

11. Cameron, L.; Van Der Zwaan, B. Employment factors for wind and solar energy technologies: A literature review. Renew. Sustain. Energy Rev. 2015, 45, 160-172. [CrossRef]

12. International Renewable Energy Agency (IRENA). Renewable Energy and Jobs-Annual Review 2019, Annual Report; IRENA: Masdar City Abu Dhabi, United Arab Emirates, 2019.

13. Blanco, M.I.; Rodrigues, G. Direct employment in the wind energy sector: An EU study. Energy Policy 2009, 37, 2847-2857. [CrossRef]

14. Dvořák, P.; Martinát, S.; Van der Horst, D.; Frantál, B.; Turečková, K. Renewable energy investment and job creation; a cross-sectoral assessment for the Czech Republic with reference to EU benchmarks. Renew. Sustain. Energy Rev. 2017, 69, 360-368. [CrossRef]

15. Okkonen, L.; Lehtonen, O. Socio-economic impacts of community wind power projects in Northern Scotland. Renew. Energy 2016, 85, 826-833. [CrossRef]

16. Comings, T.; Fields, S.; Takashi, K.; Keith, G. Employment Effects of Clean Energy Investments in Montana; Synapse Energy Economics Inc: Massachusetts, MA, USA, 2014.

17. Hondo, H.; Moriizumi, Y. Employment creation potential of renewable power generation technologies: A life cycle approach. Renew. Sustain. Energy Rev. 2017, 79, 128-136. [CrossRef]

18. Kahouli, S.; Martin, J.C. Can Offshore Wind Energy Be a Lever for Job Creation in France? Some Insights from a Local Case Study. Environ. Model. Assess. 2018, 23, 203-227. [CrossRef]

19. IEA. World Energy Outlook 2019. 2019. Available online: https://webstore.iea.org/world-energy-outlook2019 (accessed on 3 November 2019).

20. Bilgili, M.; Yasar, A.; Simsek, E. Offshore wind power development in Europe and its comparison with onshore counterpart. Renew. Sustain. Energy Rev. 2011, 15, 905-915. [CrossRef]

21. IRENA. Renewable Energy Jobs: Status, Prospects Policies, IRENA Working Paper; IRENA: Masdar City Abu Dhabi, United Arab Emirates, 2011.

22. Tranfield, D.; Denyer, D.; Smart, P. Towards a methodology for developing evidence-informed management knowledge by means of systematic review. Br. J. Manag. 2003, 14, 207-222. [CrossRef]

23. Murray, R. Why write for academic journals? In Writing for Academic Journals; McGraw-Hill Education: New York, NY, USA, 2013; pp. 10-35.

24. Krippendorff, K. Content Analysis: An Introduction to Its Methodology; Sage: Thousand Oaks, CA, USA, 2004.

25. Wilding, R.; Wagner, B.; Seuring, S.; Gold, S. Conducting content-analysis based literature reviews in supply chain management. Supply Chain Manag. 2012, 17, 544-555.

26. Moreno, B.; Lopez, A.J. The effect of renewable energy on employment. The case of Asturias (Spain). Renew. Sustain. Energy Rev. 2008, 12, 732-751. [CrossRef]

27. Wei, M.; Patadia, S.; Kammen, D.M. Putting renewables and energy efficiency to work: How many jobs can the clean energy industry generate in the US? Energy Policy 2010, 38, 919-931. [CrossRef]

28. Ejdemo, T.; Söderholm, P. Wind Power, Regional Development and Benefit-sharing: The Case of Northern Sweden. Renew. Sustain. Energy Rev. 2015, 47, 476-485. [CrossRef]

29. Dalton, G.J.; Lewis, T. Metrics for measuring job creation by renewable energy technologies, using Ireland as a case study. Renew. Sustain. Energy Rev. 2011, 15, 2123-2133. [CrossRef]

30. Blanco, I.; Kjaer, C. Wind at Work: Wind Energy and Job Creation in the EU.; European Wind Energy Association: Brussels, Belgium, 2009.

31. Jenniches, S.; Worrell, E.; Fumagalli, E. Regional economic and environmental impacts of wind power developments: A case study of a German region. Energy Policy 2019, 132, 499-514. [CrossRef] 
32. Lehr, U.; Nitsch, J.; Kratzat, M.; Lutz, C.; Edler, D. Renewable energy and employment in Germany. Energy Policy 2008, 36, 108-117. [CrossRef]

33. Lehr, U.; Lutz, C.; Edler, D. Green jobs? Economic impacts of renewable energy in Germany. Energy Policy 2012, 47, 358-364. [CrossRef]

34. Steinberg, D.; Porro, G.; Goldberg, M. Preliminary Analysis of the Jobs and Economic Impacts of Renewable Energy Projects Supported by The $\$ 1603$ Treasury Grant Program; National Renewable Energy Laboratory (NREL): Golden, CO, USA, 2012.

35. Tourkolias, C.; Mirasgedis, S. Quantification and monetization of employment benefits associated with renewable energy technologies in Greece. Renew. Sustain. Energy Rev. 2011, 15, 2876-2886. [CrossRef]

36. Garrett-Peltier, H. Green versus brown: Comparing the employment impacts of energy efficiency, renewable energy, and fossil fuels using an input-output model. Econ. Model. 2017, 61, 439-447. [CrossRef]

37. Van der Zwaan, B.; Cameron, L.; Kober, T. Potential for renewable energy jobs in the Middle East. Energy Policy 2013, 60, 296-304. [CrossRef]

38. Maia, J.; Giordano, T.; Kelder, N.; Bardien, G.; Bodibe, M.; Du Plooy, P.; Jafta, X.; Jarvis, D.; Kruger-Cloete, E.; Kuhn, G.; et al. Green Jobs: An Estimate of the Direct Employment Potential of A Greening South African Economy, Industrial Development Corporation, Development Bank of Southern Africa, Trade and Industrial Policy Strategies; Industrial Development Corporation, Development Bank of Southern Africa: Johannesburg, South Africa, 2011.

39. Singh, V.; Fehrs, J. The Work that Goes into Renewable Energy; Renewable Energy Policy Project (REPP): Washington, DC, USA, 2001.

40. Cai, M.; Cusumano, N.; Lorenzoni, A.; Pontoni, F. A comprehensive ex-post assessment of RES deployment in Italy: Jobs, value added and import leakages. Energy Policy 2017, 110, 234-245. [CrossRef]

41. Kattumuri, R.; Kruse, T. Renewable technologies in Karnataka, India: Jobs potential and co-benefits. Clim. Dev. 2019, 11, 124-137. [CrossRef]

42. Pollin, R.; Garrett-Peltier, H. Building A Green Economy: Employment Effects of Green Energy Investments for Ontario (No. Green_Economy_of_Ontario); Political Economy Research Institute, University of Massachusetts at Amherst: Amherst, MA, USA, 2009.

43. Llera, E.; Aranda, A.; Zabalza, I.; Scarpellini, S. Local impact of renewables on employment: Assessment methodology and case study. Renew. Sustain. Energy Rev. 2010, 14, 679-690. [CrossRef]

44. Brown, J.P.; Pender, J.; Wiser, R.; Lantz, E.; Hoen, B. Ex post analysis of economic impacts from wind power development in US counties. Energy Econ. 2012, 34, 1743-1754. [CrossRef]

45. Pollin, R.; Garrett-Peltier, H.; Heintz, J.; Hendricks, B. Green Growth: A U.S. Program for Controlling Climate Change and Expanding Job Opportunities; Political Economy Research Institute, University of Massachusetts at Amherst: Amherst, MA, USA, 2014.

46. Walwyn, D.R.; Brent, A.C. Renewable energy gathers steam in South Africa. Renew. Sustain. Energy Rev. 2015, 41, 390-401. [CrossRef]

47. Mu, Y.; Cai, W.; Evans, S.; Wang, C.; Roland-Holst, D. Employment impacts of renewable energy policies in China: A decomposition analysis based on a CGE modeling framework. Appl. Energy 2018, 210, 256-267. [CrossRef]

48. Mauritzen, J. The effect of wind power investments on rural labor markets. In Transforming Energy Markets. In Proceedings of the 41st IAEE International Conference, International Association for Energy Economics, Groningen, The Netherlands, 10-13 June 2018.

49. Pembina Institute. Canadian Renewable Electricity Development: Employment Impacts; Pembina Institute: Toronto, Japan, 2004.

50. Kammen, D.; Kapadia, K.; Fripp, M. Putting Renewables to Work: How Many Jobs CAN the Clean Energy Industry Create. In Report of the Renewable and Appropriate Energy Laboratory; University of California: Berkeley, CA, USA, 2004.

51. McKinsey Consulting. Wind, Oil and Gas: The Potential of Wind; McKinsey and Company: Washington, DC, USA, 2006.

52. Yelle, L.E. The learning curve: Historical review and comprehensive survey. Decis. Sci. 1979, 10, $302-328$. [CrossRef]

53. Lindman, Å.; Söderholm, P. Wind power learning rates: A conceptual review and meta-analysis. Energy Econ. 2012, 34, 754-761. [CrossRef] 
54. Grafström, J.; Lindman, A. Invention, innovation and diffusion in the European wind power sector. Technol. Forecast. Soc. Chang. 2017, 114, 179-191. [CrossRef]

55. Llera, E.; Scarpellini, S.; Aranda, A.; Zabalza, I. Forecasting job creation from renewable energy deployment through a value-chain approach. Renew. Sustain. Energy Rev. 2013, 21, 262-271. [CrossRef]

56. Böhringer, C.; Keller, A.; Van der Werf, E. Are green hopes too rosy? Employment and welfare impacts of renewable energy promotion. Energy Econ. 2013, 36, 277-285. [CrossRef]

57. Böhringer, C.; Rosendahl, K.E. Greening electricity more than necessary: On the cost implications of overlapping regulation in EU climate policy. J. Appl. Soc. Sci. Stud. 2011, 131, 469-492. [CrossRef]

58. Hillebrand, B.; Buttermann, H.G.; Behringer, J.M.; Bleuel, M. The expansion of renewable energies and employment effects in Germany. Energy Policy 2006, 34, 3484-3494. [CrossRef]

59. Frondel, M.; Ritter, N.; Schmidt, C.M.; Vance, C. Economic impacts from the promotion of renewable energy technologies: The German experience. Energy Policy 2010, 38, 4048-4056. [CrossRef]

60. Schumpeter, J.A. The creative responses in economic history. J. Econ. Hist. 1947, 7, 149-159. [CrossRef]

61. Rutovitz, J.; Atherton, A.M. Energy Sector Jobs to 2030: A Global Analysis; Institute for Sustainable Futures (UTS): Sydney, Australia, 2009; pp. 1-117.

62. Grafström, J. Technological Change in the Renewable Energy Sector: Essays on Knowledge Spillovers and Convergence. Ph.D. Thesis, Luleå University of Technology, Luleå, Sweden, 2017.

63. Grafström, J. International knowledge spillovers in the wind power industry: Evidence from the European Union. Econ. Innov. New Technol. 2018, 27, 205-224. [CrossRef]

(C) 2019 by the authors. Licensee MDPI, Basel, Switzerland. This article is an open access article distributed under the terms and conditions of the Creative Commons Attribution (CC BY) license (http://creativecommons.org/licenses/by/4.0/). 